\title{
THE RECEPTION OF LUKE AND ACTS IN THE PERIOD BEFORE IRENAEUS ${ }^{1}$
}

\section{Andrew Gregory}

This thesis sets out to ask the question of what evidence is available for the reception of Luke and of Acts in the second century. Each text is treated separately, for there is no evidence that they circulated together. Each discussion follows a similar structure, which is to examine first the earliest manuscript evidence, and to turn next to the earliest explicit external testimony to either text. The majority of the discussion then addresses the evidence of potential allusions to and citations from each of Luke and Acts in Christian writings that survive from the period before Irenaeus.

Part One, The Introduction, surveys previous scholarship and establishes the parameters of the thesis. Literary dependence (following Koester) is considered to be established wherever a second century text includes material that may be identified as the redactional work of Luke. This is a methodologically rigorous criterion which guards against the possibility that two authors have made use independently of common sources and traditions, so that any results obtained from its implementation may be considered secure, but it is not without its limitations. Thus, as the thesis notes, this criterion may be applied to only a selection of the evidence that may be relevant to the question of the reception of Luke and Acts in the second century.

Part Two of the thesis addresses the evidence for the reception of Luke. It argues that the surviving manuscript tradition may cast very little light on the reception of Luke in the second century, and that it is impossible to get behind the traditional account of Luke and Acts that is first witnessed to by Irenaeus and the Muratorian Fragment. Therefore any earlier information concerning the knowledge and use of Luke in the second century must be obtained from possible quotations from and allusions to Luke in extant texts. Texts are

${ }^{1}$ Andrew Gregory, The Reception of Luke and Acts in the Period before Irenaeus (DPhil thesis, University of Oxford, 2001); supervisor: Prof. C.C. Rowland. A revised version is forthcoming from J.C.B. Mohr [Siebeck] in the WUNT series. 
considered according to the heuristic criterion of whether they consist mainly of sayings or narrative material.

The first narrative considered is Ignatius' account of a postresurrection appearance of Jesus which shows striking affinities with Luke 24. Neither the possibility that this citation suggests an early textual form of Luke 24:39 nor the possibility that Ignatius paraphrased this account may be firmly excluded, but the evidence suggests that Ignatius is more likely to present an account similar to but independent of Luke. This conclusion therefore suggests that even Luke-like Jesus tradition need not presuppose Luke. This passage is the first of several examples of material that might be taken as independent evidence of sources underlying the Lucan passion, resurrection and ascension accounts. Similar examples are also found in our discussion of the Longer Ending of Mark and the writings of Justin. The former contains a number of striking parallels with Lmaterial in Luke, but an inability to demonstrate that this material reflects Lucan composition rather than the use of sources makes it very difficult to draw firm conclusions. Firm evidence of one instance of Lucan redactional material is found in the Gospel of the Ebionites, and Luke is seen to be presupposed in Tatian's Diatessaron, although difficulties in reconstructing the Diatessaron make it difficult to draw precise conclusions about its use of Luke.

The thesis argues that no firm evidence may be established from the Didache as to whether or not its sayings material presupposes Lucan redactional material. The presence of triple-tradition in $2 \mathrm{Cle}$ ment means that it is possible to demonstrate the use of Luke in some instances, although some evidence is found also to suggest that some Luke-like sayings may have been drawn from a source similar to Luke and not from Luke. Thomas is shown to depend on Luke in at least some instances where Thomas drew on sayings known from tripletradition and where the text of Thomas is extant in Greek.

Given that these sources suggest both that Luke was known to at least some Christians writing in the second century, and that there may also have been in circulation other sources and traditions similar to but distinct from Luke, it is not possible to point to a consistent picture of the reception of Luke on the basis of these texts. None provides evidence to demonstrate any extensive use of Luke, and Marcion appears to be the first person who can be demonstrated to have used Luke in this way.

Recent study of Marcion's Pauline corpus has called into question the degree to which he shaped and edited his text of Paul. This thesis 
demonstrates that there is no evidence supporting the belief that Marcion drew on Luke because of its association with Paul, and the precarious nature of the evidence supporting the belief that he made drastic cuts to Luke according to his own Tendenz. It leaves open the possibility that Marcion may have received a recension of Luke which was not yet associated with the name of Luke, and which did not yet contain the infancy narrative.

The thesis then discusses the evidence from Justin, who draws extensively on both sayings and narrative material concerning Jesus. Justin's writings show many parallels with Lucan material. However it is very difficult to ascertain whether most parallels reflect literary dependence on Luke, direct or indirect, or Justin's independent use of sources that were also used by Luke. Nevertheless, a number of instances of the presence of Lucan redactional material in his work demonstrate that Luke was written and in circulation in time to be drawn on by Justin, even if other Luke-like materials were also available.

Part Three investigates the early evidence, such as there is, for the reception of Acts. The text of Acts emerges from obscurity in two forms around the end of the second century, but the debate as to the origin of these text-forms lies outside the scope of this thesis. Thus, as is the case for Luke, there is no manuscript evidence to demonstrate whether the accounts of Acts in Irenaeus and the Muratorian Fragment reflect long standing independent tradition, or knowledge based only on the internal evidence of the text of Acts read alongside the Pauline corpus.

The extant writings of Justin Martyr, the Epistle of the Apostles, and the postulated source of Pseudo-Clementine Recognitions 1:27-71 all show a number of parallels to Acts, but it seems impossible to find any material in these parallels that may be considered to betray the results of Lucan redactional activity unless prior decisions are made about the sources and historicity of Acts. Three texts - the Acts of Paul, the Acts of John and the testimony of Eusebius' Anonymous in his account of the rise of the new Prophecy - do suggest that their authors have drawn on Acts, but it is very difficult to date these texts and it is possible that none antedates Irenaeus.

The Conclusion then draws together and compares the results obtained in Part Two and Part Three. It notes that difficulties in deciding the extent to which tradition peculiar to Luke is to be considered either as composition or as redaction means that Koester's criterion for establishing literary dependence may not be applied with 
any rigour to much of the potential evidence for the reception of LukeActs. Therefore it calls into question a number of assumptions that are made in the practice of source and redaction criticism. So too it questions whether the date usually assigned to Luke-Acts is secure. Finally, it notes that neither the primary evidence nor the scholarly methodology available to evaluate that evidence is sufficient to offer a detailed account of the reception of Luke-Acts in the period before Irenaeus. Thus there remains an important sense in which this thesis provides not definitive answers to the question addressed, but rather the delineation of a point beyond which scholarship is unable to go on the basis of the sources and critical approaches available at present. 